\title{
Social Values in Jalur Dance
}

\author{
Juma Afrison*, Juju Masunah \\ Art Education Program, School of Postgraduate Studies \\ Universitas Pendidikan Indonesia \\ Bandung, Indonesia \\ *jumaafrison@gmail.com
}

\begin{abstract}
Social value studies are often applied to people's lives to measure the good or bad of an act or object valued. This study discussed social values in Jalur dance, which develops in the Kuantan Singingi community. This study employed a qualitative approach, while the method used was descriptive analysis. The data were collected through a literature study, interviews, and documentation studies. Based on preliminary studies, the movements in Jalur dance have social values. Historically, this dance depicts the social life of the Kuantan Singingi community having social activities such as the tradition of Pacu Jalur that is often carried out by the Kuantan Singingi community. Pacu Jalur is always conducted on special occasions such as events commemorating Muslim holidays: Eid al-Fitr, Eid al-Adha, the Prophet's birthday, or commemorating the new year of Hijri. Meanwhile, movements such as the Search for Wood, Worship, Mangonji, Manobang, Mancaruak, Throwing, Bathing, Maelo, and Racing, are the visualizations of imitation of social activities which become one of the inspirations of movement in Jalur dance.
\end{abstract}

Keywords—social values, jalur dance

\section{INTRODUCTION}

The study of social values often cannot be separated from the study of cultural values [1]. This situation can be seen from a large number of studies regarding the local cultural values in measuring the pros and cons of individual social behavior in a social environment [2]. Value functions as a guide for one's behavior to be more orderly and cultured [3]. This is due to the existence of culture in a society that is always closely related to the identity of the community [4,5]. Another context for the concept of social value is often associated with issues of exchange value or economic problems of a society [6-8]. In this case, the meaning of social value is related to individual interaction activities in producing something [9-12]. However, social values in Indonesian society can be demonstrated by the behavior of mutual help, cooperation, and gotong-royong [13].

Social problems are always closely related to cultural problems [14-18]. Art is one of the cultural products [19-21]. Each of the regional cultures in Indonesia has unique characteristics and varies among regions, including the Kuantan Singingi community's culture.

Historically, the birth of the Jalur dance was inspired by a tradition called Pacu Jalur, which is held once a year. Initially the implementation of this tradition was intended to commemorate the Muslim holidays, such as Eid al-Fitr, Eid alAdha, the Prophet's birthday, or to commemorate the new year of Hijri. During the colonial period, the Pacu Jalur event was used as an activity to commemorate the birthday of Queen Wilhelmina (the Queen of the Netherlands). This activity is usually held in November each year. After Indonesian independence, the Pacu Jalur festival was held to commemorate the Independence Day of the Republic of Indonesia [22,23]. Nowadays, Pacu Jalur starts from April at the district level, and peaks in August in the city of Teluk Kuantan joined by every district in Kuantan Singingi Regency, neighboring districts, provinces, and also neighboring countries.

The existence of Jalur dance in Riau Province, especially in Kuantan Singingi community, is inspired by the cultural activities of Pacu Jalur carried out by the community that has been going on since the colonial era until now [24]. In certain community groups, this dance is always associated with society's belief [25-27]. This is because, in the same position, the existence of art is always associated with religious issues [28-31]. It can be seen as Jalur dance performances are always displayed on Islamic holidays. The study of dance will help understand societal problems [32-36]. Dance is the language of emotions and expressions [37-39] of an individual or society to convey all the desires of the feelings of their soul. A dance can underlie the philosophy of a society [40-43].

Jalur dance, as one of the Kuantan Singingi community's cultural identities, has a unique form of presentation. This uniqueness can be developed into one of the teaching materials for dance materials in learning cultural arts in schools. This dance is categorized as a pair dance that can be performed by two or more dancers in pairs. The Jalur dance movements consist of searching for wood, worshiping, chopping wood, mencaruk (punching holes in the body of wood), bathing, maelo (pulling) the path, and racing. These movements are full of social values that can be applied to students in learning dance to improve their cooperation in learning cultural arts.

The purpose of this research is expected to provide an overview of the social values contained in Jalur dance that has developed in the Kuantan Singingi community. The problem in this study is more focused on studying social values in the Jalur dance from the aspect of the meaning of motion that is 
displayed in the Jalur dance. Hence, this research is considered important as an effort to preserve the culture of the Kuantan Singingi community in educating the public about the meaning of values in the Jalur dance in Riau Province.

\section{RESEARCH METHODOLOGY}

This research was carried out using a qualitative paradigm with the approach of entochoreology, sociology, and anthropology. These methods were employed to get an overview of the social values in the Jalur dance that has developed in the Kuantan Singingi community. Meanwhile, data were collected through direct observations and interviews from sources of information obtained by the researcher so that the researcher could obtain a comprehensive picture of the object under study following the circumstances and facts in the field.

\section{A. Research Participants}

There were three participants (one choreographer, one dancer, one Kuantan Singingi community leader) from several participants who were considered capable of sharing data and information about social values in Jalur dance. The three participants were interviewed regarding issues that become the focus of discussion in this research. Interviews with choreographers were conducted to obtain information about the material or ideas that would be used, form of presentation, motion, the meaning of motion, and other concepts related to Jalur dance. The second interview with the dancer was to reveal information about the material of motion transferred from the choreographer to the dancer (impressions and messages) regarding the movements learned when studying the Jalur dance. The third interview was conducted with Kuantan Singingi community leader to obtain information about cultural activities carried out by the community related to the Pacu Jalur tradition.

Data analysis was performed using data triangulation techniques. The data triangulation technique is used to check the validity of the data obtained so that they are valid. This technique is often used in qualitative research to gain confidence regarding the correctness of research data found during research [44].

\section{RESULTS}

\section{A. Background of the Creation Process of Jalur Dance}

The story behind the creation of Jalur dance has to do with the community activities that support it. The dance describes a community's traditions and becomes one of the cultural products of the community of Kuantan Singingi Regency, Riau Province. In its tradition, the people of Kuantan Singingi always carry out Pacu Jalur Tradition. This tradition is held in the form of a fast race against the Kuantan river using a traditional boat from Kuantan Singingi Regency. The type of boat used by the participants, often referred to as Anak Pacu, is a type of traditional boat made by the local community. The boat itself has a length of 30 meters or more with a diameter of about 2 meters. The boat used comes from a tree chiseled by a group of people, and the result is a boat used in Pacu Jalur, which is always held by the people of Kuantan Singingi Regency. One example of the occasion carrying out Pacu Jalur is commemorating the Prophet's birthday or celebrating the Hijri New Year. This type of boat can accommodate about 40 to 60 people.

In the Great Dictionary of the Indonesian Language, Pacu means a sharp object or toothed wheel attached to the heel of a shoe (worn by a horse rider), to trigger a horse to run fast. While Jalur means a straight column; broad line; wide strip; 2. the space between two lines on a large surface; 3. a space extending between two rows of plants; 4. rails; 5 . a space extending between two straight lines; the space between the single play line and the dual play line. Meanwhile, in the context of this research, the term Pacu Jalur means a canoe rowing competition or traditional boat race held at Batang Narosa Edge, Kuantan River, Taluk Kuantan, Kuantan Singingi Regency, Riau Province. In addition, the term Jalur means a longboat made of wood with a length of about 25-30 meters with a diameter of 1-2 meters.

In its development, Jalur dance was first created in 1990 by a choreographer, Zainal Abidin. One of the motivations for the creation of the dance was because he was requested by the Regent of Indragiri Hulu, Rukiyat Syaifudin. The Regent asked Zainal Abidin to create Jalur dance in order to celebrate the first national event of Pacu Jalur in 1991. Since it was first performed in Pacu Jalur event, Jalur dance has always been performed in Pacu Jalur event. It is often performed in several other events such as in various traditional art performances in Riau Province.

\section{B. Form of Jalur Dance Presentation}

Jalur dance is a new creation dance that collaborates local traditional dance idioms with new creative forms inspired by Pacu Jalur activity held by the people of Kuantan Singingi, Riau. One of the characteristics of this type of dance is that the pattern is different from existing forms in its expression. The movements created in the Jalur dance are in various forms, such as the movement to find wood, worshiping, making konji, cutting trees, mencaruk (scratching), throwing away, bathing, maelo, and racing. As mentioned earlier, all of those are new forms of movements created by a choreographer in efforts to interpret and express the activities of the Kuantan Singingi community of Riau province in a series of activities in participating in Pacu Jalur tradition. The dance movements created by the choreographer intends to provide values and messages related to the process of the Kuantan Singingi people of Riau Province in preparing themselves to participate in the Pacu Jalur activity. The activity starts from looking for wood into the forest to make a lane or longboat, up to the dancers' portrayal when swinging the boat rowing, on which the local people call the boat as Jalur.

One of the newly created dance work caharacteristics is that it has a novelty from the previous traditional form. Therefore, 
most of the new dance creations are in great demand by the audience [45]. In the case of Jalur dance, it gives a new nuance to the appreciators of dance in the Kuantan Singingi community of Riau province in presenting a new form of dance that shows the local spirit community. The spirit of gotongroyong, cooperating, and helping, become the strength of the theme in carrying out the identity of the Kuantan Singingi community, Riau.

\section{Structure of Movement of Jalur Dance}

Several concepts of creative dance work always emphasize the three concepts: the emphasis on the concept of action, creativity, and encouragement to fulfill the aesthetic needs of dance [46]. This theory can also be seen in the lineage dance work developed by the choreographer to fulfill dance aesthetics in accordance with the purpose of the dance creation. Jalur dance is very thick with elements of choreographer's creativity in actualizing Pacu Jalur tradition's imagae in his dance works. This image be seen from the structure of Jalur dance movement as follows.

1) Searching for wood movement: The movement to search for the wood is the initial movement of Jalur dance. This movement is carried out from outside the stage by forming a diagonal floor pattern with two lines between male dancers and female dancers. This motion includes a meaningful motion (gesture) which describes a person going into the rimbo (forest) because the road to the rimbo has a lot of bushes, twigs, and branches that hinder the journey, so the bushes, the twigs, and the branches must be cleaned to make a smooth passage.

2) Worshipping movement: Worship movement is a form of gesture of worship using a low level. This form of motion uses more head and hand movements. When viewed from the shape of the motion, this movement is a meaningful motion (gesture). This worship movement aims to ask permission to the host of the tree before the tree is cut, and the surrounding community often calls it mambang.

3) Mangonji movement: The movement of mangonji is a gesture that mimics a person squeezing flour performed by female dancers using a low level of motion and is more dominant in hand movements. Mangonji movement is a category of gesture motion. In this movement, female dancers move like mothers who are wringing flour. The relationship between mengonji movement and Jalur dance is that the activity of mengonji becomes one of the activities of women in making traditional foods of Teluk Kuantan, which can always be found in every big event held by Teluk Kuantan community.

4) Manobang movement: The movement of mangonji is a gesture that mimics a person squeezing flour performed by female dancers using a low level of motion and is more dominant in hand movements. Mangonji movement is a category of gesture motion. In this movement, female dancers move like mothers who are wringing flour. The relationship between mengonji movement and Jalur dance is that the activity of mengonji becomes one of the activities of women in making traditional foods of Teluk Kuantan, which can always be found in every big event held by Teluk Kuantan community.

5) Mencaruk movement: This movement is performed by male dancers, in a vertical pattern in a circle. This movement is done by rotating in a semicircle with a hand's swing up and down like a person making a hole. This rotation of the hand follows the direction of the rotation of the footsteps. Mencaruk movement is classified as a meaningful motion or gesture. This movement depicts the lane-making workers making holes or cavities in the wood used as the lane. The movement is faster and more agile than manobang or cutting down trees.

6) Throwing out movement: The throwing movement describes the movement of a person throwing away scratching the wood. This movement is performed by male dancers. From the form of motion, this movement of throwing away is classified as a meaningful motion or gesture. When viewed from the shape of the motion, this movement provides an image or meaning of throwing away a thing. This throwing away movement is not a pure form of throwing away, but has been refined into a form of dance.

7) Bathing movement: The bathing movement depicts the ancient times of the people of Teluk Kuantan. They did all of their activities in the Kuantan River, such as daily activities, trading, etc. Meanwhile, the wood seekers who have finished making Jalur will go to the Kuantan River to bathe or clean up (interview with Maifadal Muin).

8) Maelo movement: This movement is performed by men and women in a row pattern and using the rower property. Maelo's movement also gives a meaning of cooperation or solidarity, because maelo means pulling Jalur. Maelo Jalur movement is a category of moving motion or locomotion.

9) Racing movement: The racing movement is classified as pure motion, and the form of the motion resembles a person racing. The racing motion uses a low level and consists of three tempo forms, namely fast, medium, and slow. The movement is purely like those racing on the banks of Narosa.

\section{Social Values in Jalur Dance}

TABLE I. STUDY OF SOCIAL VALUES IN JALUR DANCE

\begin{tabular}{|c|c|l|}
\hline No & Result of Study & \multicolumn{1}{c|}{ Description } \\
\hline 1 & Theme of Dance & $\begin{array}{l}\text { Provide an overview of the activities of } \\
\text { the Kuantan Singingi community in } \\
\text { doing gotong royong, working together, } \\
\text { helping each other in preparing their } \\
\text { groups to participate in Pacu Jalur } \\
\text { tradition. }\end{array}$ \\
\hline
\end{tabular}


Table 1. Cont.

\begin{tabular}{|l|l|l|}
\hline \multirow{3}{*}{2} & $\begin{array}{l}\text { The movement to search for the wood, } \\
\text { The Concept of worhip mangonji, manobang, } \\
\text { Movement } \\
\text { mencaruk, movement of throwing out, } \\
\text { movement of bathing, maelo, and racing } \\
\text { movement are the concepts of working } \\
\text { on movements that emphasize more on } \\
\text { the description of the social activities of } \\
\text { the Kuantan Singingi community in } \\
\text { taking parts in Pacu Jalur tradition } \\
\text { activities. }\end{array}$ \\
\hline 3 & $\begin{array}{l}\text { Jalur dance is mostly performed in } \\
\text { community activities that aim to tie the } \\
\text { social values of the local community to } \\
\text { work together, cooperate with each } \\
\text { other, and help each other in organizing } \\
\text { the Pacu Jalur tradition which is always } \\
\text { displayed in events commemorating } \\
\text { Muslim holidays, such as Eid al Adha. }\end{array}$ \\
\hline
\end{tabular}

\section{CONCLUSION}

Based on previous explanation, the researcher draws the following conclusions.

- The social values in Jalur dance emphasize the description of the traditional activities of the community of Kuantan Singingi, Riau Province, in organizing Pacu Jalur tradition. The tradition is always held in certain events, such as events commemorating Muslim holidays, for example, Eid Al-Adha.

- Social values in Jalur dance are expressed through some of the main movements, namely searching for wood, worship, mangonji, manobang, mencaruk, throwing away, bathing, maelo, and racing. To summarize, Jalur dance movement depicts Pacu Jalur activity. Thus, Pacu Jalur movement is a visualization of the imitation of social activities, which is used as an inspiration for movement in Jalur dance.

\section{REFERENCES}

[1] Y. Gloriani, "Kajian Nilai-Nilai Sosial Dan Budaya Pada Kakawihan Kaulinan Barudak Lembur Serta Implementasinya Dalam Pembelajaran Bahasa Dan Sastra Indonesia Berbasis Multikultural". Lokabasa. 4(2). 2013.

[2] D.P. Silondae, "Model Bimbingan Kelompok Berbasis Nilai Budaya Suku Tolaki untuk Meningkatkan Keterampilan Sosial Siswa". J Bimbing Konseling. 2(2). 2013.

[3] N. Suwardani, "Pewarisan Nilai-nilai Kearifan Lokal untuk Memproteksi Masyarakat Bali dari Dampak Negatif Globalisasi". J Kaji Bali (Journal Bali Stud. 5(2):247-64. 2015.

[4] P. Astuti, "The Essence of Siganjua Lalai Values in Dance Movements of Minangkabau Women". Harmon J Arts Res Educ. 19(1):37-47. 2019.

[5] Y. Nursyam, S. Supriando, "Makna Simbolik Tari Ilau Nagari Sumani, Kabupaten Solok Sumatera Barat". Panggung. 28(4). 2018.

[6] J. Schumpeter, "On the concept of social value". Q J Econ. 23(2):21332. 1909.

[7] G.W. Lundeen, The growth of social knowledge: theory, simulation, and empirical research in group processes. Greenwood Publishing Group; 2002.

[8] A. Schweitzer, "Social values in economics". Rev Soc Econ. 39(3):25778. 1981.
[9] K.J. Arrow, "Methodological individualism and social knowledge". Am Econ Rev. 84(2):1-9. 1994.

[10] J.M. Epstein, R. Axtell, Growing artificial societies: social science from the bottom up. Brookings Institution Press, 1996

[11] L. Udehn, Methodological individualism: Background, history and meaning. Routledge, 2002.

[12] G.M. Hodgson, "Meanings of methodological individualism". J Econ Methodol. 14(2):211-26. 2007.

[13] A.D. Wildan, M. Dulkiah, I. Irwandi, "Pemaknaan dan Nilai dalam Upacara Adat Maras Taun di Kabupaten Belitung". Panggung. 29(1). 2019

[14] M. Lamy, K. Zourou, Social networking for language education. Springer. 2013.

[15] S.M. Choi, Y. Kim, Y. Sung, D. Sohn, "Bridging or bonding? A crosscultural study of social relationships in social networking sites". Information, Commun Soc. 14(1):107-29. 2011.

[16] H. Hu, W. Cui, J. Lin, Y. Qian, "ICTs, social connectivity, and collective action: A cultural-political perspective". J Artif Soc Soc Simul. 17(2):7. 2014.

[17] R. Shneor, K. Efrat, "Analyzing the impact of culture on average time spent on social networking sites". J Promot Manag. 20(4):413-35. 2014.

[18] S. Ting-Toomey, T. Dorjee, Communicating across cultures. Guilford Publications. 2018.

[19] R. Johnson, "What is cultural studies anyway?" Soc text. (16):38-80 1986.

[20] S. Hall, "Cultural studies: Two paradigms". Media, Cult Soc. 2(1):5772. 1980.

[21] J.D. Slack, "The theory and method of articulation in cultural studies". Stuart Hall Crit dialogues Cult Stud. 112-27. 1996.

[22] H. Hasbullah, R.A. Ashori, M.N. al-Masri, "Unsur-unsur Magis dalam Tradisi Pacu Jalur: Perspektif Antropologi Agama". Sos Budaya. 13(1):25-44. 2016.

[23] H. Hasbullah, "Dimensi Mistik Dalam Event Pacu Jalur". Sos Budaya. 14(2):190-9. 2017.

[24] H. Mahardi, E. Erlisnawati, "Nilai Karakter Dalam Budaya Pacu Jalur Pada Masyarakat Teluk Kuantan Provinsi Riau". J Ilm Pendidik Guru Sekol Dasar. 1(1). 2017.

[25] J. Hellman, "Performing the nation: cultural politics in new order Indonesia". Vol. 89. Nias Press; 2003.

[26] T. Jones T. Kebudayaan dan kekuasaan di Indonesia: Kebijakan budaya selama abad ke 20 hingga Era Reformasi. Yayasan Pustaka Obor Indonesia; 2015.

[27] R. Wessing, "A dance of life; The seblang of Banyuwangi, Indonesia. Bijdr tot taal-", land-en volkenkunde/Journal Humanit Soc Sci Southeast Asia. 155(4):644-82. 1999.

[28] G. St John, "Electronic dance music culture and religion: An overview". Cult Relig. 7(1):1-25. 2006.

[29] M. Nye, Religion: the basics. Routledge; 2008.

[30] G. Lynch, "The role of popular music in the construction of alternative spiritual identities and ideologies". J Sci Study Relig. 45(4):481-8. 2006.

[31] G. St John, "Trance tribes and dance vibes: Victor Turner and electronic dance music culture". Victor Turn Contemp Cult Perform. 149-73. 2008 .

[32] C.J. Novack, Sharing the dance: Contact improvisation and American culture. Univ of Wisconsin Press. 1990.

[33] A.L. Kaeppler, "Dance in anthropological perspective". Annu Rev Anthropol. 7(1):31-49. 1978.

[34] M. Harris, Cultural anthropology. HARPER \& ROW, 1987.

[35] J.R. Giersdorf, Y. Wong, The Routledge dance studies reader. Routledge. 2010.

[36] A.L. Kaeppler, "II. Dance ethnology and the anthropology of dance". Danc Res J. 32(1):116-25. 2000 
[37] J. Blacking, "Movement and meaning: Dance in social anthropological perspective". Danc Res. 1(1):89-99. 1983.

[38] L. Naveda, M. Leman, "The spatiotemporal representation of dance and music gestures using topological gesture analysis (TGA)". Music Percept. 28(1):93-111. 2010.

[39] G. Gore, Traditional dance in West Africa. In: Dance History. Routledge. p. 73-94. 2006.

[40] A.L. Kaeppler, Dance. Int Encycl Commun. 2008.

[41] S. Kapper, "Estonian Folk Dance: Terms and Concepts in Theory and Practice". Folk Electron J Folk. (54):73-96. 2013.
[42] M. Ostashewsky, S. Johnson, K. Walsh, "Dance in Canada: Contemporary Perspectives". Ethnologies (Que). 30(1):5-20. 2008.

[43] M. Lant, To Create A Nation: Folk Culture and the Construction of Identity. 2018.

[44] B.S. Bachri, "Meyakinkan Validitas Data Melalui Triangulasi Pada Penelitian Kualitatif". Teknol Pendidik. 10:46-62. 2010.

[45] Syefriani, "Tari Kreasi Baru Zapin Seribu Suluk Pada Masyarakat Pasir Pengaraian Kabupaten Rokan Hulu". J Chem Inf Model. 53(9):1689-99. 2019.

[46] Santoso, Tari turonggo seto; sebuah kreasi baru berbasis rakyat. 2014. 